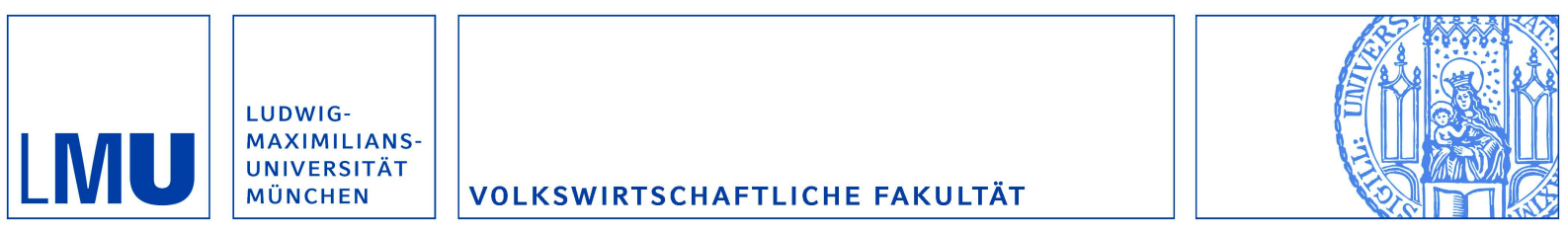

Dischinger, Matthias und Riedel, Nadine:

Corporate Taxes and the Location of Intangible Assets Within Multinational Firms

Munich Discussion Paper No. 2008-15

Department of Economics

University of Munich

Volkswirtschaftliche Fakultät

Ludwig-Maximilians-Universitä† München

Online at https://doi.org/10.5282/ubm/epub.5294 


\title{
Corporate Taxes and the Location of Intangible Assets Within Multinational Firms
}

\author{
Matthias Dischinger* \\ University of Munich
}

\author{
Nadine Riedel ${ }^{\dagger}$ \\ University of Munich
}

Version: July 28, 2008

\begin{abstract}
Intangible assets, like patents and trademarks, are increasingly seen as the key to competitive success and as the drivers of corporate profit. Moreover, they constitute a major source of profit shifting opportunities in multinational enterprises (MNEs) due to a highly intransparent transfer pricing process. This paper argues that for both reasons, MNEs have an incentive to locate intangible property at affiliates with a relatively low corporate tax rate. Using panel data on European MNEs and controlling for unobserved time-constant heterogeneity between affiliates, we find that the lower a subsidiary's tax rate relative to other affiliates of the multinational group the higher is its level of intangible asset investment. This effect is statistically and economically significant, even after controlling for subsidiary size and accounting for a dynamic intangible investment pattern.
\end{abstract}

JEL classification: H25, F23, H26, C33

Keywords: multinational enterprise, intangible assets, tax planning, micro level data

*Seminar for Economic Policy, Department of Economics, University of Munich, Akademiestr. 1/II, 80799 Munich, Germany, phone: +49-89-2180 2279, e-mail: matthias.dischinger@lrz.uni-muenchen.de.

${ }^{\dagger}$ Public Finance Group, Department of Economics, University of Munich, Ludwigstr. 28/Vgb./III, 80539 Munich, Germany, phone: +49-89-2180 2874, e-mail: nadine.riedel@lrz.uni-muenchen.de.

We are indebted to Tobias Boehm, Dhammika Dharmapala, Peter Egger, Harry Grubert, Andreas Haufler, Nils Herger, Socrates Mokkas, Johannes Rincke, Richard Schmidtke and to participants of seminars at the University of Munich, the Summer Symposium 2008 of the Oxford University Centre for Business Taxation, the Meeting of the Association for Public Economic Theory 2008 and the CESIfo Venice Summer Institute 2008 for helpful comments. Financial support of the German Research Foundation (DFG) is gratefully acknowledged. 


\section{Introduction}

In recent years, intangible assets have gained increasing importance in the corporate production process (e.g. Hall, 2001). Since access to financial capital has been substantially improved, key physical assets are less scarce (Zingales, 2000) and intangible factors related to product innovation and marketing are increasingly seen as the key to competitive success (Edmans, 2007). Hence, intangibles like patents, trademarks, customer lists and copyrights have become major determinants of firm value. This development is especially significant in multinational enterprises (MNEs). ${ }^{1}$ While until the early 1990ies, MNEs commonly raised little or no fee from their corporate affiliates for the use of patents or trademarks, owners of these intangibles have - in line with updated legal regulations and accounting standards - started to charge for their immaterial goods and, thus, intangibles-related intra-firm trade has surged.

Since then, an increasing number of anecdotes has reported that MNEs transfer their valuable intangible property to low-tax jurisdictions. Famous examples are Pfizer, Bristol-Myers Squibb and Microsoft which have relocated a considerable part of their research and development (R\&D) units and patents from their home countries to Ireland (see e.g. Simpson, 2005, on Microsoft's R\&D transfer). Others founded trademark holding companies in tax havens that own and administer the group's brands and licenses. E.g. Vodafone's intangible properties are held by an Irish subsidiary, and Shell's central brand management is located at a Swiss affiliate from where it charges royalties to operating subsidiaries worldwide. Moreover, an increasing number of financial consultancies advocates multinational tax planning strategies that imply the relocation of intangible property to low-tax affiliates. ${ }^{2}$

Governments and tax authorities have raised increasing concerns about these relocation examples (Hejazi, 2006). They fear that the trend to fragment corporate production by locating value-driving intangible intermediate goods in low-tax economies diminishes the multinational corporate tax base in their countries. Moreover, arm's length

\footnotetext{
${ }^{1}$ Empirical evidence links the presence of intangible property to the emergence of MNEs. Intangibles are perceived to foster FDI since they "can be easily transferred back and forth and [...] enjoy a public good nature which makes them available to additional production facilities at relatively low costs" (Markusen, 1995; Gattai, 2005).

${ }^{2}$ Examples are the British brand valuation consultancy Brand Finance plc whose client list includes world-wide operating MNEs like British American Tabacco, Danone, Shell or Foster's (Brand Finance plc, 2008) and the renowned US law firm Morgan, Lewis \& Bockius LLP (Morgan Lewis \& Bockius LLP, 2007).
} 
prices for firm-specific intangibles are hard to determine (see e.g. Grubert, 2003; Desai et al., 2006), which gives rise to the additional concern that MNEs may shift profits earned at production affiliates in high-tax countries to the intangibles-holding low-tax affiliate by overstating the true transfer price for royalties and license fees.

Surprisingly though, it has, to the best of our knowledge, not yet been clarified within an empirical framework whether these relocation examples are individual cases or represent a systematic multinational investment pattern. We investigate this question using panel data on European MNEs and find evidence for a statistically significant and quantitatively relevant bias of intangible property holdings towards affiliates with a low corporate tax rate relative to other group locations.

To receive guidance for the specification of our estimation model, the paper starts out with a short section on theoretical considerations. We argue that MNEs have an incentive to relocate intangible property to low-tax countries for two reasons. First, intangible property is increasingly perceived to be the driver of (multinational) firm profit. As immaterial goods may easily be locally separated from other production units in the group, the MNE has an incentive to locate them at low-tax countries in order to tax the accruing rents at a small rate. Second, MNEs may have an incentive to locate their intangible property at a low-tax affiliate for profit shifting reasons. Conditional on the assumption that intra-firm trade of intellectual property rights establishes increased transfer pricing opportunities between the intangibles owner and the group's production affiliates, it pays to locate intangibles at a low-tax affiliate since this generates profit shifting channels between the intangibles-holding tax haven and all other affiliates located in countries with a higher corporate tax rate. In contrast, intangibles location at one of the group's high-tax affiliates generates shifting possibilities solely between the tax haven and the intangibles-holding firm whereas other high-tax affiliates remain without shifting link to a low-tax country. The paper argues that for both reasons, the location of intangible property becomes more attractive the lower the subsidiary's corporate tax rate relative to other group locations.

The empirical section employs a large panel data set of multinational affiliates within the EU-25 which is available for the years 1995 to 2005. Our data is drawn from the micro database AMADEUS that provides detailed accounting information at the affiliate level and allows identification of a multinational group's ownership structure. Following our theoretical considerations, we determine the effect of an affiliate's average statutory corporate tax rate difference to other group members on its level of intangible asset investment. Controlling for unobserved time-constant heterogeneity between subsidiaries, year effects, country characteristics and affiliate size, the results confirm 
our expectations and point to a robust inverse relation between the subsidiary's statutory tax rate relative to other group affiliates and its intangibles holdings. The effect is statistically and economically significant and appears across a range of specification and estimation choices that address endogeneity issues and the dynamic nature of the intangible asset investment. Quantitatively, the estimations suggest a semi-elasticity of around 1.1, meaning that a decrease in the average tax differential to other group affiliates by 10 percentage points raises a subsidiary's intangible property investment by around $11 \%$ on average.

The paper adds to the literature on corporate taxation and multinational firm behavior. In the last years, research in this area has largely focused on the investigation of profit shifting activities. Various papers show that affiliate pre-tax profitability (i.e. profits per input factor or sales) is inversely related to the statutory corporate tax rate and the tax rate differential to other group members, respectively (see Huizinga and Laeven, 2008, for a recent paper). These results are usually interpreted as indirect evidence for profit shifting activities through the distortion of multinational transfer prices and/or the group's equity dept structure. Our paper suggests that this profitability pattern may be established by a third mechanism which is the relocation of profit-driving intangible property to low-tax affiliates. Although these relocations may also be induced by the desire to optimize transfer pricing opportunities (as described above), the relocation of value-driving assets itself generates the respective profitability pattern even in the absence of shifting activities.

Our paper moreover relates to existing work that connects the presence of intangible property holdings to multinational profit shifting behavior arguing that the true price for firm-specific intangible property is hard to control for national tax authorities and henceforth multinationals could easily engage in transfer pricing manipulations (e.g. Grubert, 2003). Moreover, there is some evidence that MNEs adjust their organization and investment structure to optimize profit shifting opportunities. For example, Grubert and Slemrod (1998) and Desai et al. (2006) find that parent firms with high intangible asset investments and henceforth good opportunities to engage in profit shifting activities are most likely to invest in tax havens. Analogously, Grubert (2003) shows that R\&D intensive MNEs engage in significantly larger volumes of intra-group transactions and thus create more opportunities for income shifting. However, none of these papers considers the location of intangible property within the multinational group to be a choice variable of the MNE. To the best of our knowledge, we are the first to show in a systematic econometric approach that MNEs distort the location of their value-driving and shifting-relevant intangibles towards low-tax affiliates in the 
multinational group. The only exception we are aware of is a recent paper by Grubert and Mutti (2007) who point out that US parents' R\&D investment has become a weak predictor for royalty payments from foreign subsidiaries to the US parent but simultaneously strongly enlarges the earnings of group affiliates located in tax havens. They interpret their results to reflect the parents' incentive to found hybrid entities in tax havens and to reach favorable cost sharing agreements on R\&D investment with them. The hybrids then sell patent licenses to high-tax production affiliates and receive the corresponding royalty payments as earnings.

The remainder of the paper is structured as follows. Section 2 presents a short motivation of the hypothesis tested in our empirical model. In Section 3, we describe our data and the sample construction. Section 4 states the basic estimation methodology. The estimation results are presented in Section 5. Finally, Section 6 concludes.

\section{A Rationale for Intangible Asset Location at Low-tax Countries}

Our paper's purpose is to empirically investigate whether corporate taxation distorts the location of intangible assets within a corporate group as suggested by growing anecdotic evidence. ${ }^{3}$ For a better understanding, we will in the following shortly sketch potential rationales behind the (re)location of intangible property at (to) low-tax countries. We will thereby refer to two motives. Firstly, it pays for MNEs to locate highly profitable intangible assets at tax havens and, secondly, intangibles location at a lowtax county may optimize the multinational profit shifting strategy.

In general, it is widely acknowledged that a large fraction of MNEs in industrialized economies is horizontally organized with production locations in several countries (e.g. Markusen, 2002). The manufacturing of the final output good thereby often requires a set of intangible inputs (e.g. patents, trademarks or management services). In the last years, these intangible assets have been increasingly perceived to be the major determinants of firm value while the actual output production only generates relatively low profit margins. A classic example are producers of pharmaceutical articles which earn their profit by developing innovative patents and promote brand names on the

\footnotetext{
${ }^{3}$ We follow the notion that there is an optimal location pattern for intangible assets across group affiliates in the absence of corporate taxation, i.e. some affiliates are more efficient in developing and administering intangible property than others (e.g. due to a higher proportion of high-skilled workers at the respective hosting locations). Corporate taxes distorts this optimal location pattern.
} 
consumer market while the manufacturing of the drugs usually does not yield considerable returns. This provides a strong incentive to fragment the corporate production process and to locate the highly profitable intangible production assets at countries with a relatively low tax rate while the low-profit production of the final output good remains in the (high-tax) consumer markets (see Becker and Fuest, 2007, for a related theoretical argument). Low relocation costs of intangibles relative to tangible goods additionally foster this development.

Moreover, profit shifting incentives may strengthen this distortion of intangible asset holdings towards low-tax locations. Since intangible property owners charge royalty payments and license fees to operating affiliates worldwide, it enables the MNE to shift profits between the intermediate holding affiliate and all production locations by distorting the respective intra-firm transfer price. Supporting this line of argumentation, recent papers relate profit shifting activities to intangible asset ownership (e.g. Grubert, 2003 or Desai et al., 2006) as arm's length prices for firm-specific intellectual property rights are hard to determine for tax authorities. The MNE may now optimize its profit shifting opportunities by choosing the optimal location of intangible assets across affiliates. Intuitively, holding intangibles at a low-tax affiliate generates a profit shifting link between the intangibles-holding tax haven affiliate and all other group members. Therefore, profit may be shifted from each high-tax affiliate to the intangibles-holding company in the low-tax country. In contrast, if the intangibles were located at one of the high-tax affiliates, the MNE would gain only one profit shifting link to the tax haven affiliate while all other affiliates in high-tax countries would lack shifting opportunities to a low-tax country. Obviously, this provides an additional incentive to locate intangible assets at affiliates with a relatively low corporate tax rate.

Both arguments laid out above suggest that MNEs have an incentive to locate their intangible property holdings at affiliates with a low corporate tax rate difference to other group members. The lower a subsidiary's corporate tax rate relative to other group affiliates, the larger its attractiveness to become the owner of intangible property that would otherwise (in the absence of taxation) be located at another group location. Strictly speaking, the marginal investment decision would depend on the difference in the effective marginal tax rates between the locations (see Devereux and Griffith, 1998). For various reasons, we will employ the difference in the statutory corporate tax rates instead whereas this modification will be discussed in detail in section 4 . Moreover, the incentive to locate intangible assets at low-tax affiliates for the purpose of optimizing profit shifting strategies is indeed given by the differences between the multinational affiliates' statutory corporate tax rates. The larger these differentials the more the MNE 
profits from relocating one unit of earnings from a high-tax to the low-tax affiliate and consequently the larger the gains from shifting activities.

Following these considerations, MNEs have an incentive to locate intangible property at affiliates with a small corporate tax rate compared to other group locations which is in line with recent evidence of multinational intangibles relocations to tax havens. ${ }^{4}$

\section{Data Set}

Our empirical analysis employs the commercial database AMADEUS which is compiled by Bureau van Dijk. The version of the database available to us contains detailed information on firm structure and accounting of 1.6 million national and multinational corporations in 38 European countries from 1993 to 2006, but is unbalanced in structure. ${ }^{5}$ We focus on the EU-25 and on the time period of 1995-2005 as these countries and years are sufficiently represented by the database. The observational units of our analysis are multinational subsidiaries within the EU-25. ${ }^{6}$ Since our analysis also requires data on the subsidiary's parent company (e.g. the number and location of the parent's subsidiaries), we investigate only subsidiaries whose parents are likewise located within the EU-25 and on which information is available in the AMADEUS database.

Moreover, our analysis accounts only for industrial subsidiaries whose foreign parent is likewise an industrial corporation and owns at least three subsidiaries (by more than $90 \%$ of the ownership shares). The latter assumption ensures that the MNEs in

\footnotetext{
${ }^{4}$ MNEs have several strategies at hand to organize (re)location of intangible property (to) at low-tax countries. Strategies related to the exploitation of favorable cost-sharing agreements are, for example, described by Sullivan (2004). Another common strategy is to split up R\&D and marketing departments respectively, in the sense that a (small) fraction of the departments is located at a tax haven and the rest of the departments remains at a high-tax location. The units located at a low-tax affiliate then carry out major projects (with high expected returns) and provide service subcontracts to the R\&D and marketing units in the high-tax countries. The latter earn a fixed margin on their costs while the low-tax affiliate bears the risk of the project and consequently earns all residual profits.

${ }^{5}$ The AMADEUS database is also widely used outside the scientific community. For example, tax authorities (e.g. in Germany and France) are known to rely on AMADEUS for their monitoring activities. The same is true for tax consultanties (e.g. Deloitte Touche Tohmatsu and KPMG).

${ }^{6}$ Our criteria of being a multinational enterprise is the existence of a foreign immediate shareholder (parent) which holds at least $90 \%$ of the affiliate's ownership shares. The data restriction to firms which are owned by $90 \%$ or more ensures that the potential location of profit and intangibles at this subsidiary is relevant for the multinational group.
} 
our sample exhibit a sufficient size so that strategical allocation of intangibles may emerge. In addition, we restrict the sample to multinational groups that actually own immaterial assets, i.e. either the parent or at least one of its subsidiaries has to hold intangibles. Last, we drop MNEs which observe a negative profit at all group affiliates throughout the sample period since they are then not subject to positive tax payments and profitability and/or profit shifting considerations are henceforth irrelevant.

[Table 1 here]

Our sample contains firms from all EU-25 countries despite Cyprus and Malta. The country statistics are presented in Table 1 . The intangibles measure is the balance sheet item intangible fixed assets. ${ }^{7}$ Since many firms in the database report no information on this variable, our panel data consists of 45,575 observations from 6,732 multinational subsidiaries for the years 1995-2005. Hence, we observe each affiliate for 6.8 years on average.

The AMADEUS data has the drawback that information on the ownership structure is available for the last reported date only which is the year 2004 for most observations in our sample. Thus, in the context of our panel study, there exists some scope for misclassifications of parent-subsidiary-connections since the ownership structure may have changed over the sample period. However, in line with previous studies, we are not too concerned about this issue since the described misclassifications introduce noise to our estimations that will bias our results towards zero (see e.g. Budd et al., 2005).

${ }^{7}$ All balance sheet and profit \& loss account items in our analysis are exported from AMADEUS in unconsolidated values. The balance sheet item intangible asset investments reflects the immaterial property holdings of an affiliate whereas two cases have to be considered. First, the multinational affiliate develops the immaterial good on its own. Then, according to all relevant accounting standards, it is forbidden to capitalize the intangible asset in early development stages. However, in later stages, e.g. with the application for a patent or an official trademark, the assets are capitalized in the balance sheet on the basis of the production costs. The second case is that the multinational affiliate purchases the intangible good from another group affiliate or a third party. Here, the intangible asset is capitalized in the balance sheet at the purchase value. Since our data does not allow us to distinguish between own-produced intangible assets and bought intangible property, we can a priori not exclude potential endogeneity issues here. Nevertheless, since we consider an affiliate's capacity to produce intangible property to be determined mainly by time-constant characteristics (e.g. the fraction of high-skilled workers in the local labor market that is largely invariant over a ten year time period) which are absorbed by the affiliate fixed effects, we are not too concerned about the issue. Moreover, we will address this problem in a robustness check, estimating a binary choice model for intangibles holdings at a certain affiliate which is not prone to capitalization issues. 
[Table 2 here]

Table 2 displays the sample statistics. The mean of the intangible asset variable is calculated with 3.4 million US dollars at the subsidiary level (however with a large standard deviation of 117 million) and with 64.8 million at the parent level (again with a large standard deviation of 785 million). To compare the intangible investment on the subsidiary and on the parent level in relative terms, we calculate the share of intangible assets to total assets. The mean of this ratio is about $50 \%$ higher for subsidiaries $(2.6 \%)$ than for parent firms (1.7\%). We moreover define a variable binary intangible assets which takes on the value 1 if a subsidiary owns intangible assets and 0 otherwise. The sample average is measured to be 0.5519 and hence $55.2 \%$ of the subsidiaries in our sample hold intangible property. In addition, the affiliates in our data belong to multinational groups with on average 81.4 subsidiaries that are owned by at least $90 \%$ of the ownership shares. This rather high mean value is thereby driven by a few very large MNEs, as the median of the subsidiary number distribution is calculated with 26. Furthermore, on average, a subsidiary holds total assets amounting to 105 million US dollars and observes an operating revenue of 82.2 million.

We additionally merge data on the statutory corporate tax rate at the subsidiary and parent location, as well as basic country characteristics like GDP per capita (as a proxy for the degree of development), population (as a proxy for the market size) and the unemployment rate (as a proxy for the economic situation of a country). ${ }^{8}$ For the affiliates in our sample, the statutory corporate tax rate spreads from $10.0 \%$ to $56.8 \%$ whereas the mean is calculated with $33.3 \%$ on the subsidiary level and with $36.2 \%$ on the parent level. Our theoretical considerations presuppose that the level of intangible assets may moreover be inversely related to an affiliate's corporate tax rate relative to other group members. We therefore define the average tax difference to all other affiliates which is the unweighted average statutory corporate tax rate difference between a subsidiary and all other affiliates of the corporate group (including the parent) that are owned by at least $90 \%$ of the ownership shares. This tax difference spreads from $-38.2 \%$ to $28.7 \%$ with a mean of $-0.7 \%$. Although our subsidiary sample comprises European firms only, the calculation of the average tax difference to all other affiliates accounts for information on the worldwide structure of the corporate group which is

\footnotetext{
${ }^{8}$ The statutory tax rate data for the EU-25 is taken from the European Commission (2006). Our analysis will moreover rely on tax rates for group affiliates outside the EU as will be explained below. This data is obtained from KPMG International (2006). Country data for GDP per capita, population size and unemployment rate are taken from the European Statistical Office (Eurostat).
} 
generally available with the AMADEUS data. However, for non-European subsidiaries, this information generally comprises only the subsidiaries' names, hosting countries and ownership shares but no accounting information. Therefore, an appropriate weighting procedure for our tax difference variable is not feasible and we employ an unweighted average tax measure. ${ }^{9}$

[Figure 1 and Figure 2 here]

Last, the descriptive statistics strongly confirm the increasing importance of intangible property in corporate production over the last decade. Figures 1 and 2 report the average level of intangible asset investment at subsidiaries and parents in our sample between 1995 and 2005. While the average parent firm owns substantially more intangible property than the average subsidiary, the mean value steeply rises for both types over the years which is in line with previous findings in the literature (e.g. Hall, 2001).

\section{Econometric Approach}

We employ different methodological approaches to test the hypothesis formulated in Section 2. The following paragraphs present our baseline estimation model as well as various robustness checks that account for alternative specifications, endogeneity issues and a dynamic model of intangible asset investment.

\subsection{Baseline Model}

In our baseline regression, we estimate an OLS model of the following form

$$
\log \left(y_{i t}\right)=\beta_{1}+\beta_{2} \tau_{i t}+\beta_{3} X_{i t}+\rho_{t}+\phi_{i}+\epsilon_{i t}
$$

with $y_{i t}=($ intangible assets +1$)$. Since the distribution of intangible asset investment of subsidiary $i$ at time $t$ is considerably skewed, we employ a logarithmic transformation

\footnotetext{
${ }^{9}$ We experimented with size-weighted equivalents of this average tax difference variable. Since the application of a weighting scheme is only sensible if we observe information on the subsidiaries' size variable for all or at least the vast majority of the group affiliates, this leads to a drastic reduction in sample size as the information on affiliate accounts is often not available for as sufficient number of group subsidiaries. Nevertheless, we found the application of weighted tax measures to lead to qualitatively comparable results which are available from the authors upon request.
} 
of the level of intangible assets as dependent variable. Furthermore, a substantial fraction $(44.8 \%)$ of the subsidiaries in our dataset does not hold any intangible assets at all and thus, we follow previous studies (e.g. Plassmann and Tideman, 2001; Alesina et al., 2002; Hilary and Lennox, 2005; Weichenrieder, 2008) and add a small constant (=1) to our intangibles variable to avoid that zero-observations are excluded from the estimation. The explanatory variable of central interest is $\tau_{i t}$ which stands the subsidiary's statutory corporate tax rate difference to all other affiliates of the multinational group (that are owned with at least $90 \%$ of the ownership shares) including the parent. One might also consider to apply the effective marginal tax rate differences to identify the subsidiary's marginal intangibles investment (see also Devereux and Griffith, 1998). However, commonly available effective marginal (and average) tax rates usually refer to investment projects in the manufacturing industry and do not appropriately reflect intangibles related investments. Since deductibility rules may substantially differ between investment forms, we do not consider these effective tax measures to suit well in our regression context and employ the statutory tax rate as a proxy instead. Given the commonly reported high correlation between the effective marginal and the statutory corporate tax rates, we consider this approach to be valid. ${ }^{10}$ Moreover, as suggested by Section 2, the statutory corporate tax rate difference simultaneously captures the incentive to locate intangible property at low-tax countries for profit shifting purposes.

Furthermore, $X_{i t}$ comprises a vector of time-varying country control characteristics like GDP per capita, population size and the unemployment rate. These macro controls are included to ensure that the results are not driven by an unobserved correlation between a country's wealth, market size and economic situation (as proxied by the above variables) with corporate taxes and intangible investment. The variables will enter in logarithmic form although this is neither qualitatively nor quantitatively decisive for our results. Furthermore, a full set of year dummies $\rho_{t}$ is included to capture shocks over time common to all subsidiaries. $\epsilon_{i t}$ describes the error term. Since we apply panel data, we are able to add subsidiary fixed effects to control for non-observable, timeconstant firm-specific characteristics $\phi_{i}$. Using fixed-effects is reasonable and necessary in our analysis since a firm's level of intangible assets is likely to be driven by internal firm-specific factors which are impossible to be captured by observable control variables available in our data set. The fixed-effects model is also preferred to a random-effects approach by a Hausman-Test.

Starting from this baseline approach, we investigate the sensitivity of our results to

\footnotetext{
${ }^{10}$ Nevertheless, we experimented with effective marginal corporate taxes and found qualitatively comparable effects on intangible asset investment.
} 
alternative model specifications.

\subsection{Robustness Check I: Binary Dependent Variable}

In a first sensitivity check, we take into account that $44.8 \%$ of the subsidiaries in our data do not exhibit any intangible property holdings at all. This data structure indicates it to be a relevant multinational choice whether or not to locate intangible property at an affiliate at all and that a binary choice model might fit the data well. Thus, the sensitivity check comprises a model of the following form

$$
b_{i t}=\gamma_{1}+\gamma_{2} \tau_{i t}+\gamma_{3} X_{i t}+\rho_{t}+\phi_{i}+v_{i t}
$$

whereas $b_{i t}$ represents the binary intangible assets variable that takes on the value 1 if a subsidiary owns intangible property and the value 0 otherwise. The explanatory variables are specified analogously to equation (1). Again the regression includes time-constant affiliate fixed effects and year dummies. In a first step, we determine the coefficient estimates for equation (2) based on maximum-likelihood techniques by estimating a fixed-effect logit model. The model thereby critically relies on the assumption that the error term $v_{i t}$ follows a logistic distribution. As an additional check to our results, we thus reestimate equation (2) in a linear probability framework based on the standard OLS assumptions. ${ }^{11}$

\subsection{Robustness Check II: Size Control}

In a second sensitivity check, we extend our baseline estimation and additionally control for affiliate size. Conditioning intangible asset investments on affiliate size may be decisive since otherwise our tax measure might reflect the widely-tested negative impact of corporate taxation on subsidiary size only. It is well-known that low corporate tax rates foster affiliate investment and vice versa. If large affiliates also tend to hold high investments in intangible property, the corporate tax effect determined in our baseline estimation may be contaminated by the underlying negative relation between corporate taxes and affiliate size.

\footnotetext{
${ }^{11}$ The data structure suggests the estimation of a truncated regression model. However, truncated models like tobit are not feasible with affiliate fixed effects. Since subsidiary fixed effect turn out to be decisive in our empirical analysis, we consider the application of a binary fixed-effect logit and an OLS model respectively to be an appropriate alternative.
} 
To circumvent this issue, we include the subsidiary's total capital investment as control variable. ${ }^{12}$ This may, however, give rise to obvious reverse causality problems since intangible assets may well determine an affiliate's volume of total capital investment. We therefore employ the levels estimator proposed by Anderson and Hsiao (1982) which suggests to control for time constant affiliate effects by taking the first differences of the estimation equation and to instrument for the difference in the endogenous variable (here: total assets) by employing lagged levels of this variable. ${ }^{13}$ Thus, we use a two-stage instrumental variables approach (2SLS) to estimate the following model

$$
\Delta \log \left(y_{i t}\right)=\beta_{2} \Delta \tau_{i t}+\beta_{3} \Delta X_{i t}+\beta_{4} \Delta \log \left(a_{i t}\right)+\Delta \rho_{t}+\Delta \epsilon_{i t}
$$

whereas $y_{i t}, \tau_{i t}, X_{i t}$ and $\epsilon_{i t}$ correspond to the variables defined in Section 4.1 and $a_{i t}$ stands for the total asset investment of subsidiary $i$ at time $t$. Moreover, $\Delta$ indicates the first difference operator. Our result tables will report the F-statistic for the relevance of the instruments at the first stage of the regression model and a Sargan/Hansen-Test of overidentifying restrictions which tests for the validity of the instruments employed, i.e. for their exogeneity with respect to the error term $\Delta \epsilon_{i t}$.

\subsection{Robustness Check III: Dynamic Model}

Last, our estimation approach so far did not take into account that relocating intangible property within the MNE might be associated with considerable positive adjustment costs. For example, relocating corporate R\&D units and/or the associated patent rights from one affiliate to another is associated with a move of workers and tangible assets and henceforth implies relocation costs. Thus, we expect a subsidiary's intangibles holdings in previous periods to be a predictor for intangible assets investment today and include the first lag of a subsidiary's intangible asset investment $y_{i, t-1}$ as additional explanatory variable in our estimation equation.

The well-known dynamic panel bias implies that including the first lag of the dependent variable as additional control in a fixed-effects framework leads to biased

\footnotetext{
${ }^{12}$ Our results are robust against the use of alternative proxies for subsidiary size, e.g. the subsidiaries' operating revenue.

${ }^{13}$ With panel data on more than two time periods, it is not equivalent to apply a fixed-effect and first-differencing approach respectively. Both models give unbiased and consistent estimates although the relative efficiency of the estimators may differ, depending on the model structure. Precisely, the fixed-effect estimator is less sensitive against the violation of strict exogeneity of the regressors while the first-differencing estimator is less sensitive against the violation of serially uncorrelated error terms. In the result section, we will discuss the relation between the fixed-effects and first--differencing results.
} 
coefficient estimates because the lagged dependent variable is endogenous to the fixed effects in the error term. Thus, we follow Arellano and Bond (1991) who build on the Anderson and Hsiao (1982) framework applied in section 4.3 and suggest to estimate a first-difference generalized method of moments (GMM) model and instrument for the first difference in the lagged dependent variable by deeper lags of the level of the dependent variable. ${ }^{14}$ The estimation equation then takes on the following form

$$
\Delta \log \left(y_{i t}\right)=\beta_{1} \Delta \log \left(y_{i, t-1}\right)+\beta_{2} \Delta \tau_{i t}+\beta_{3} \Delta X_{i t}+\beta_{4} \Delta \log \left(a_{i t}\right)+\Delta \rho_{t}+\Delta \epsilon_{i t} .
$$

The variable definitions correspond to the ones in previous sections. Because the model is estimated in first-differences, the equation will be characterized by the presence of first-order serial correlation. However, the validity of the GMM estimator relies on the absence of second-order serial correlation. The Arellano/Bond-Test for second-order serial correlation will be reported at the bottom of the result table. Again, we check for the exogeneity of the instrument set by employing a Sargan/Hansen-Test.

\section{$5 \quad$ Empirical Results}

This section presents our empirical results. Throughout all regressions, the observational units of our analysis are the multinational subsidiaries as explained in sections 3 and 4. Additionally, in all upcoming estimations, a full set of year dummy variables is included and heteroscedasticity robust standard errors adjusted for firm clusters are calculated and displayed in the tables in parentheses. Section 5.1 presents the baseline findings while section 5.2 displays the results of our robustness checks.

\subsection{Baseline Estimation}

Table 3 presents our baseline estimation. Following the methodology described in section 4.2, specification (1) regresses the logarithm of subsidiary intangible asset investment on the firm's statutory corporate tax rate, while controlling for fixed firm and year effects. In line with our theoretical considerations, we find a statistically significant negative influence that suggests high corporate tax rates at an affiliate to be associated with low intangible asset investment and vice versa. The effect is robust against the inclusion of time-varying country control characteristics in specification (2).

\footnotetext{
${ }^{14}$ Note that the difference in the lagged dependent variable correlates with the differenced error term. However, deeper lags (starting from the second lag) of the dependent variable (in levels) are available as valid instruments as they are orthogonal to the error term.
} 
[Table 3 here]

However, the subsidiaries' statutory tax rate may be an imprecise measure for tax incentives on intangible asset location since our hypothesis predicts intangibles to be located in countries with a low tax rate relative to all other affiliates of the corporate group. This is accounted for in specifications (3) and (4) which regress the level of intangible assets on the average tax difference to all other affiliates. Confirming our theoretical expectations of Section 2, the results indicate that the average statutory corporate tax rate difference between a subsidiary and other group members exerts a highly significant negative impact on the subsidiary's intangibles holdings. Quantitatively, the estimations suggest that a decrease in the average tax difference to all other affiliates by 1 percentage point raises the subsidiary's level of intangible assets by $1.6 \%$ (cf. column (4)).

\subsection{Robustness Checks}

In the following, we will determine the robustness of our results to alternative model specifications as laid out in subsections $4.2-4.4$ on the econometric methodology.

\subsubsection{Binary Dependent Variable}

In a first step, we estimate equation (2) and thus focus on the binary multinational choice whether to locate intangible property at a certain affiliate or not. The results are displayed in Table 4. Specifications (1) and (2) thereby present maximum-likelihood estimations of a fixed-effect logit model. The dependent variable is the binary intangible assets measure defined above. Since the logit estimation controls for subsidiary fixed effects, many subsidiaries drop out of the estimation since they observe no variation in the status of intangibles-holding vs. non-holding during the observation period. Nevertheless, the estimations still comprises an adequate number of about 2,200 firms for which information is available for 7.5 years on average.

[Table 4 here]

In specification (1), we regress the binary variable on the subsidiary's statutory tax rate. The coefficient estimate is negative and highly significant and thus confirms the presumption that a subsidiary's probability of holding intangible property decreases 
in the location's statutory tax rate. Moreover, specification (2) estimates the relation using the average tax difference to all other affiliates as explanatory tax variable. Again, we find a negative effect on intangibles holdings which is statistically significant at the $5 \%$ level. Thus, the lower a subsidiary's statutory corporate tax rate compared to all other affiliates of the same multinational group (including the parent), the higher is its probability of holding intangible assets. ${ }^{15}$

Nevertheless, the estimation of the fixed-effect logit model critically depends on the assumption of a logistic distribution of the error term. Thus, as a sensitivity check, we moreover estimate a linear probability model with subsidiary fixed effects. The application of an OLS framework thereby has the additional advantage that we make use of all information in our dataset and do not preclude the sample to subsidiaries which observe a change over the sample period in the status of intangibles-holding vs. non-holding. The results are displayed in specifications (3) and (4) of Table 4 and are qualitatively equal to the results of the logit model. Ceteris paribus, a reduction of the unweighted average tax difference to all other affiliates by 10 percentage points is suggested to rise the subsidiary's probability of holding intangible assets by 1.97 percentage points on average (cf. column (4)). As the mean probability of holding intangibles is $55.2 \%$, this corresponds to an average increase of $3.6 \%$.

\subsubsection{Control for Subsidiary Size}

As a second robustness check, we will determine whether our estimated corporate tax effect on intangible asset investment is robust against the inclusion of a control variable for subsidiary size. Precisely, we will condition the intangible property holdings on the subsidiary's total capital investment. To account for potential reverse causality with respect to total and intangible investment levels as described in section 4.3, we estimate the equation in first differences and employ the lagged levels of total assets as instruments for the first differences in total assets (Anderson and Hsiao, 1982).

To do so, we first compare the coefficient estimates from a first-differencing approach to the fixed-effects model and reestimate specifications (2) and (4) of Table 3 using first differences instead of fixed effects. The results are displayed in columns (1) and (2) of Table 5. While the qualitative effect of both, the statutory tax rate and the average tax difference to all other affiliates, on the level of intangible asset investment

\footnotetext{
${ }^{15}$ The coefficient estimates of a logit estimation cannot be interpreted quantitatively. Moreover, applying a logit model with fixed effects makes the calculation of marginal effects impracticable as it requires specifying a distribution for the fixed effects.
} 
remains unchanged, the point estimates are substantially smaller than for the fixedeffect regressions $(-1.17$ and -0.92 , respectively) although they do not statistically differ from each other. Since we consider unobserved heterogeneity in the subsidiary characteristics to be a major issue in our regression context, we generally presume the fixed-effects approach to deliver the more efficient estimates. Nevertheless, since the qualitative results are independent of the model employed and first-differencing delivers smaller coefficient estimates than the fixed-effect approach, we feel confident that a qualitative and a quantitative interpretation of the first-differencing model's coefficient estimates (as a lower bound) is valid.

\section{[Table 5 here]}

In specifications (3) and (4), we add the level of a subsidiary's total assets as size control whereas we treat the variable as exogenous with respect to the error term. The inclusion of this additional control does not alter the coefficient estimates of our tax variables by much. The coefficient estimate of total assets is positive and statistically significant suggesting that larger affiliates tend to hold more intangible property. However, since the specifications do not control for potential reverse causality, the coefficient estimates may be biased.

In specifications (5) and (6), we address this endogeneity problem and instrument the first difference of total assets with lagged levels of the variable. ${ }^{16}$ This modification of the estimation model slightly increases the coefficient estimates of our tax measures which remain statistically significant. Interestingly though, instrumenting for total asset investments erases the positive effect of affiliate size on intangible asset holdings now suggesting that intangible asset investment is independent of affiliate size. Moreover, the usual test statistics claim our specification to be valid since the F-test for the instruments at the first stage is highly significant indicating our instruments to be relevant. Furthermore, the null-hypothesis of the Sargan/Hansen-Test is accepted stating that the instruments are uncorrelated with the error term and henceforth valid.

\footnotetext{
${ }^{16}$ Precisely, we employ the second to fourth lag of the logarithm of total asset investment as instruments. We consider this to be an appropriate model specification since with the Anderson and Hsiao (1982) estimator, the gained information from including additional lags as instruments has to be weighted against the loss in sample size due to missing values implied by including additional lags.
} 


\subsubsection{Dynamic Estimation}

As a third sensitivity check, we determine the relation between corporate taxes and intangible asset investment in a dynamic model which additionally accounts for positive adjustment and relocation costs of intangible property. We follow Arellano and Bond (1991) and employ a one-step linear GMM estimator in first differences which implies that the endogenous differenced lag of intangible assets investments is instrumented with the second and all deeper lags of the level of intangible asset investments as explained in section 4.4. ${ }^{17}$ The results are presented in Table 6 and point to a dynamic nature of intangible asset investment since lagged intangible property holdings indeed show a significant and quantitatively relevant impact on current intangibles investments.

[Table 6 here]

Our corporate tax effects on intangible asset investment are largely unaffected by the inclusion of the lagged dependent variable and quantitatively correspond to the estimations in the non-dynamic case presented in Table 5. Specifications (1) and (2) of Table 6 document a negative and significant effect of the subsidiary's statutory tax rate and the tax difference variable on intangible asset investment. In specifications (3) and (4), we again include subsidiary total asset investment as size control whereas we treat the variable as endogenous and instrument it with the second and all deeper lags of its level. The results show a similar picture as the previous subsection. While the coefficient estimates for the corporate tax measures are unaffected by the inclusion of the size control and remain statistically significant and of quantitatively relevant size, the total asset variable itself does not exert any statistically significant effect on intangible asset holdings. Finally, in specifications (5) and (6), we additionally include the second lag of the intangible asset variable to control for a deeper dynamic effect. This second lag shows no significant effect on intangible investment and does not affect

\footnotetext{
${ }^{17}$ Note that with the Arellano and Bond (1991) estimator, we do not face the trade-off of the Anderson and Hsiao (1982) estimator that the gained information from including additional lags as instruments has to be weighted against the loss in sample size due to missing values. This applies since the Arellano and Bond (1991) methodology sets missing values to 0 and still derives a meaningful set of moments conditions. Nevertheless, we additionally reestimated all specifications of Table 6 in an Anderson and Hsiao (1982) framework and found qualitative and quantitative comparable results. Here, the F-statistic of the first-stage regression also indicates a strong relevance of the instrument set used.
} 
our qualitative tax result. Moreover, the test statistics confirm our dynamic specifications to be valid. The Arellano/Bond-Test accepts the null-hypothesis that there is no second-order autocorrelation in the error term and likewise the Sargan/Hansen-Test of overidentifying restrictions accepts the null-hypothesis that the set of instruments is exogenous to the error term.

\subsubsection{Other Robustness Checks}

Furthermore, we rerun all our specifications with the additional inclusion of a full set of 110 one-digit NACE code industry-year dummies (not reported). This addon does not change any of our qualitative and quantitative results. In addition, we checked if our results are driven by a pure Eastern European effect. We thus defined a dummy variable that takes on the value 1 if a subsidiary is located in one of the Eastern European countries (comprising the Czech Republic, Estonia, Hungary, Latvia, Lithuania, Poland, Slovakia and Slovenia) and generated interaction terms of the East European dummy with the set of year effects. Including these in our regression analysis does not alter any of the qualitative and quantitative results.

Finally, we reestimate our regressions employing the statutory corporate tax rate difference between a subsidiary and its parent firm as explanatory variable (instead of the average tax difference to all other group affiliates, including the parent). This model specification accounts for the fact that a large fraction of intangible property is traditionally held by the multinational parent firms (see Figures 1 and 2) and parents are perceived to be the natural and classic owners and administrators of intangible property since they host the MNEs' relevant management and administration departments. Regressing intangible asset investment on the tax difference to the parent captures the incentive to relocate intangibles from the parent to the considered subsidiary for tax purposes. We hence reestimate all specifications presented in this paper (including the robustness checks) using the tax difference to the parent as the relevant tax measure. This modification leads to the same qualitative results (not reported) as the models accounting for the tax structure of the whole MNE and supports the notion that taxes impact on the location of intangibles within an MNE. ${ }^{18}$

Summing up, we present empirical evidence that the lower the corporate tax rate of a subsidiary relative to all other affiliates of the multinational group the higher is its level of intangible assets. This result turns out to be robust against a set of sensitivity checks and specifications.

\footnotetext{
${ }^{18}$ The results are available from the authors upon request.
} 


\subsection{Corporate Tax Differentials and Affiliate Profitability}

The previous subsections presented evidence that intangible assets are distorted towards affiliates with a low corporate tax rate. Our theoretical motivation predicts that this distortion may root firstly in the incentive to locate highly profitable immaterial goods at countries with a relatively low corporate tax rate and, secondly, in the incentive to optimize intra-group profit shifting opportunities. Both explanations imply that the profitability observed at multinational low-tax affiliates exceeds the profitability at high-tax affiliates, either because value-driving assets are located at low-tax countries or because intangible property is used to shift profits there.

This predicted pattern is very much in line with evidence found in the extensive empirical literature on profit shifting. Several papers show an inverse relation between corporate taxes and affiliate profitability. For example, Collins et al. (1998) and Dischinger (2007) present evidence that the statutory corporate tax difference between a subsidiary and its parent firm negatively affects the subsidiary's productivity (measured as pretax profit per units of input factors). Analogously, Hines and Rice (1994), Huizinga and Laeven (2008) and an earlier discussion paper version of our paper (Dischinger and Riedel, 2008) provide evidence that affiliate productivity falls in the average tax difference to all other affiliates of the multinational group. These results are usually interpreted as indirect evidence for profit shifting activities. Our paper suggests an alternative motivation for the observed profitability pattern. We argue that it may, apart from profit shifting activities, equally be caused by the location of profit-driving intangible assets at low-tax countries.

A rigorous test of this presumption implies to show that the dependency between the corporate tax rate distribution across affiliates and the profitability pattern is more extreme in MNEs that observe a large share of their intangible asset holdings at affiliates with a relatively low corporate tax rate; i.e., profit (per unit of input factors and sales respectively) earned at low-tax affiliates is larger and profit earned at high-tax affiliates is correspondingly lower than in the absence of an intangible investment bias towards low-tax countries. However, this task is complicated and goes beyond the scope of our paper. A main issue here is that we do not observe detailed accounting data on the whole multinational group (see also section 3 on data) and henceforth cannot clearly determine the intangible asset distribution across the MNE. Moreover, the location of intangible property within a multinational firm is endogeneous and may be determined by unobserved factors that equally impact on affiliate profitability. We address this question in a companion paper (Dischinger and Riedel, 2008b) where we exploit the fact 
that the major fraction of intangible assets is still held by the parent firm (see Figures 1 and 2). ${ }^{19}$ Headquarters are moreover largely immobile in an international context and usually remain in the country where the corporation was originally founded. Thus, the parent location may be considered to be exogenous. In line with our theoretical presumptions, the companion paper finds that profitability differences between hightax and low-tax affiliates are significantly larger if the multinational headquarters, and thus a high fraction of profit-driving and shifting-relevant assets, are located in a low-tax country.

\section{Conclusions}

The last years have witnessed an increasing importance of intangible assets (patents, copyrights, brand names, etc.) in the corporate production process of MNEs (see Figures 1 and 2). Anecdotal evidence thereby suggests that these intangibles are often located at low-tax affiliates. For example, Nestle, Vodafone and British American Tabacco have created brand management units in countries with a relatively low corporate tax rate that charge royalties to operating subsidiaries worldwide. Our paper argues that these relocation tendencies are driven by two motivations. Firstly, by the incentive to save taxes through the relocation of highly profitable intangible assets to low-tax countries. Secondly, by the incentive to optimize profit shifting strategies through the distortion of transfer prices for intangible property traded within the firm. Intangibles are usually firm-specific goods for which arm's length prices can hardly be determined by tax authorities. Henceforth, MNEs may overstate the transfer price for the intermediate immaterial good at relatively low expected costs and thus shift profits from high-tax production affiliates to the intangibles-holding affiliate in the low-tax country.

To the best of our knowledge, our paper provides the first systematic empirical evidence that the location of intangible assets within MNEs is indeed distorted towards low-tax affiliates. Based on a rich data set of European MNEs during the years 1995 to 2005, we show that the lower the statutory corporate tax rate of a subsidiary relative to all other affiliates of the multinational group, the higher is the level of intangible assets at this location. This result turns out to be robust against various specifications

\footnotetext{
${ }^{19}$ The headquarters location usually hosts the MNE's central management. That most of the intangible property is still located with the MNE's central management, could be justified by the management's desire to have the decisive intangible assets under their direct control.
} 
and robustness checks. Thus, the evidence suggests that MNEs exploit the enhanced importance of intellectual property in the production process by distorting its location within the corporate group to minimize their overall tax liabilities. Quantitatively, we find a semi-elasticity of around 1.1, meaning that a decrease in the average tax difference to all other group affiliates by 10 percentage points raises a subsidiary's stock of intangibles by around $11 \%$ on average.

These behavioral adjustments have profound consequences for international corporate tax competition. First, the relocation of intangible assets to tax havens facilitates income shifting and enlarges the streams of multinational profit transferred to countries with a low tax rate. This increases the governmental incentive to lower its corporate tax rate and aggravates the race-to-the-bottom in corporate taxes. Second, it is important to stress that the creation and administration of intangible assets is related to real corporate activity. To relocate patents and trademark rights to low-tax countries, MNEs have to transfer part of their R\&D departments and their administration and marketing units with them. Obviously, these multinational service units comprise high-skilled workers who represent part of the decisive corporate human capital (see e.g. Bresnahan et al., 2002). Thus, countries which attract intangible investment by lowering their corporate tax rate do not only gain higher pre-tax profits but may also win additional jobs and knowledge capital that may spill over and increase the productivity of local firms. According to this, the gains from lowering the corporate tax rate surge along a second line and enforce tax competition behavior.

Currently, the regulations on intangibles relocation within MNEs are rather lax in many OECD countries. For example, rules with respect to cost sharing agreements between multinational affiliates are loose in the US and other OECD countries (see also Grubert and Mutti, 2007) and thus tend to foster the shift of patent rights from parent $R \& D$ departments to $R \& D$ units at low-tax affiliates. Additionally, in most OECD countries (part of) the intangible property can be relocated across borders at rather low costs. For example, if an MNE moves a production center from a high-tax country to a tax-haven, it usually has to calculate transfer prices for all tangible assets transferred while intangible goods like e.g. production plans and knowledge capital is not accounted for.

Many governments have identified these hidden intangible asset relocations from their countries as one major source of corporate tax revenue losses. For example, Germany has recently come forward with an unilateral attempt to restrict the relocation of (intellectual property owning) production units from its borders. In January 2008, a new legislation was introduced that regulates transfer prices to be charged on the 
whole relocated multinational affiliate. This implies that MNEs must calculate transfer prices not only on their tangible production units but equally have to account for the intangible value, the profit potential, of the firm. Other countries are expected to follow the German advance with the introduction of similar regulations. In the light of our paper, this tightening on relocation possibilities of intangible assets across borders should be appreciated as it reduces the potential for tax competition behavior. 


\section{Appendix}

Figure 1: Parent Level Intangible Assets over Time

(Mean of all observations per year, in thousand US dollars, current prices)

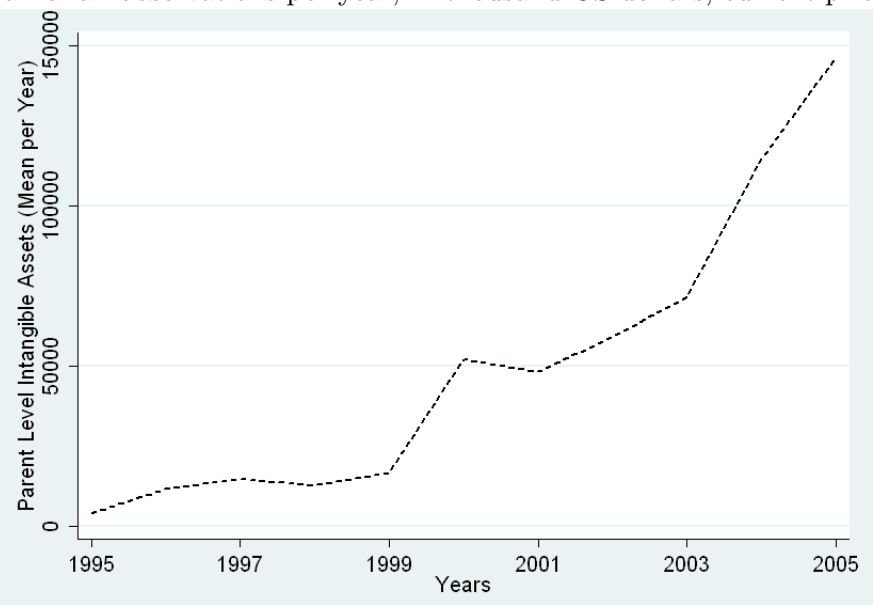

Figure 2: Subsidiary Level Intangible Assets over Time

(Mean of all observations per year, in thousand US dollars, current prices)

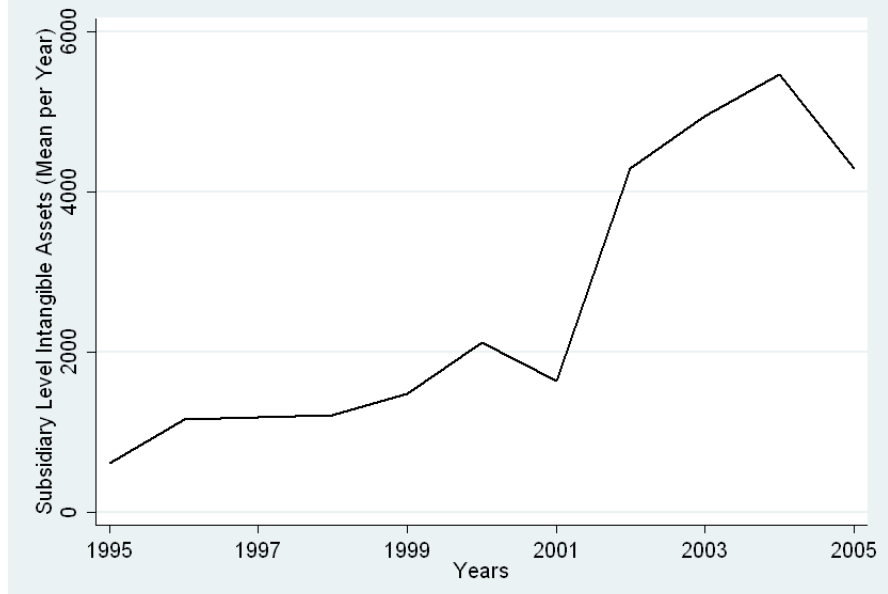




\begin{tabular}{|l|c|}
\hline \multicolumn{2}{|l|}{ Table 1: Country Statistics } \\
\hline \hline Country & Subsidiaries \\
\hline Austria & 86 \\
Belgium & 462 \\
Czech Republic & 214 \\
Denmark & 409 \\
Estonia & 123 \\
Finland & 307 \\
France & 809 \\
Germany & 309 \\
Great Britain & 949 \\
Greece & 60 \\
Hungary & 97 \\
Ireland & 107 \\
Italy & 492 \\
Latvia & 54 \\
Lithuania & 33 \\
Luxembourg & 31 \\
Netherlands & 530 \\
Poland & 391 \\
Portugal & 105 \\
Slovakia & 45 \\
Slovenia & 7 \\
Spain & 665 \\
Sweden & 447 \\
\hline Sum & 6,732 \\
\hline
\end{tabular}




\begin{tabular}{|l|ccccc|}
\hline \multicolumn{5}{|c|}{ Table 2: Descriptive Statistics } \\
\hline \hline Variable & Obs. & Mean & Std. Dev. & Min. & Max. \\
\hline Subsidiary Level: & & & & & \\
\hline Statutory Corporate Tax Rate & 45,575 & .3333 & .0632 & .1 & .5676 \\
Avg. Tax Diff. to All Other Aff. & 43,813 & -.0070 & .0634 & -.3817 & .2865 \\
Intangible Assets $\star$ & & & & & \\
Binary Intangible Assets & 45,575 & 3,420 & 116,636 & 0 & $1.03 \mathrm{e}+07$ \\
Total Assets & 45,575 & .5519 & .4973 & 0 & 1 \\
Operating Revenue & 45,575 & 105,206 & 900,066 & 2 & $7.75 \mathrm{e}+07$ \\
Ratio Intangible to Total Assets & 44,583 & 82,179 & 439,198 & 0 & $2.25 \mathrm{e}+07$ \\
& 45,575 & .0262 & .0841 & 0 & 1 \\
Parent Level: & & & & & \\
Statutory Corporate Tax Rate & 45,575 & .3624 & .0725 & .1 & .5676 \\
Intangible Assets & 36,223 & 64,845 & 784,666 & 0 & $1.98 \mathrm{e}+07$ \\
Number of Subsidiaries & 45,575 & 81.4 & 135.6 & 3 & 752 \\
Ratio Intangible to Total Assets & 36,223 & .0173 & .0546 & 0 & .9924 \\
Country Level: & & & & & \\
\hline GDP per Capita (in Euro) & 45,575 & 21,877 & 8,333 & 1,517 & 60,311 \\
Population (per thousand) & 45,575 & 34,588 & 24,274 & 406 & 82,537 \\
Unemployment Rate & 45,217 & .0863 & .0365 & .021 & .199 \\
\hline
\end{tabular}

Notes:

A The Average Tax Difference to All Other Affiliates is calculated as: statutory corporate tax rate of the considered subsidiary minus the unweighted average statutory corporate tax rate of all other group members, comprising subsidiaries (owned with at least $90 \%$ of the ownership shares) and the parent firm.

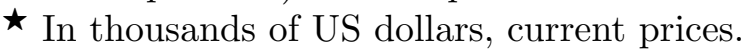

- Binary Intangible Assets takes on the value 1 if a subsidiary owns intangible assets and takes on the value 0 if a subsidiary does not own any intangibles.

- Subsidiaries owned with $\geq 90 \%$ of the ownership shares. Median is calculated with 26 . 
Table 3: Baseline Estimation: Subsidiary's Level of Intangibles

OLS Fixed-Effects, Panel 1995-2005

Dependent Variable: Log Intangible Assets

\begin{tabular}{|l|cccc|}
\hline \hline Explanatory Variables: & (1) & (2) & (3) & (4) \\
\hline Statutory Tax Rate & $-2.440^{* * *}$ & $-1.968^{* * *}$ & & \\
Avg. Tax Difference to All Other Affiliates & $(.6366)$ & $(.6635)$ & & \\
& & & $-2.041^{* * *}$ & $-1.598^{* * *}$ \\
Log GDP per Capita & & & $(.5638)$ & $(.5804)$ \\
& & -.2115 & & -.2167 \\
Log Population & & $(.2178)$ & & $(.2240)$ \\
& & -2.446 & & $-3.006^{*}$ \\
Log Unemployment Rate & & $(1.592)$ & & $(1.617)$ \\
& & .1238 & & .1227 \\
Number of Observations & & $.0906)$ & & $(.0934)$ \\
Number of Firms & 45,575 & 45,217 & 43,813 & 43,467 \\
Adjusted $R^{2}$ & 6,732 & 6,732 & 6,473 & 6,473 \\
\hline & .7627 & .7638 & .7618 & .7630 \\
\hline
\end{tabular}

Notes: Heteroscedasticity robust standard errors adjusted for firm clusters in parentheses. ${ }^{*},{ }^{* *},{ }^{* * *}$ indicates significance at the $10 \%, 5 \%, 1 \%$ level. The observational units are multinational subsidiaries that exhibit a foreign parent which owns at least $90 \%$ of the ownership shares. Additionally, to be included in the estimation, at least one affiliate of a corporate group has to own intangible assets and at least one has to make positive profits. The dependent variable is the natural logarithm $(\log )$ of the level of intangible assets; we add a small constant to the initial level to avoid losing observations with zero intangibles by taking the logarithm. An OLS model with fixed firm effects is estimated. The variable Average Tax Difference to All Other Affiliates is defined as the unweighted average statutory tax rate difference between the considered subsidiary and all other affiliates of the corporate group including the parent. All regressions include year dummy variables. Adjusted $R^{2}$ values are calculated from a dummy variables regression equivalent to the fixed-effects model. 


\begin{tabular}{|l|cccc|}
\hline \multicolumn{5}{|c|}{ Table 4: Robustness Check I: Binary Dependent Variable } \\
Logit \& OLS Fixed-Effects, Panel 1995-2005 \\
Dependent Variable: Binary Intangible Assets \\
\hline \hline Explanatory Variables: & $(1)$ & $(2)$ & $(3)$ & $(4)$ \\
\hline Statutory Tax Rate & $-3.935^{* * *}$ & & $-.3352^{* * *}$ & $(.1035)$ \\
Avg. Tax Difference to All Other Affiliates & $(1.126)$ & & $-.1972^{* *}$ \\
& & $-2.557^{* *}$ & & $(.1010)$ \\
GDP per Capita & & $(1.083)$ & & .1581 \\
& 1.868 & $3.907^{* *}$ & -.0008 & $(.1315)$ \\
Population & $(1.917)$ & $(1.904)$ & $(.1347)$ & $-1.492^{* *}$ \\
Unemployment Rate & $-22.31^{* * * *}$ & $-21.34^{* * * *}$ & $-1.580^{* * * *}$ & $-1.6358)$ \\
& $(7.321)$ & $(7.464)$ & $(.6186)$ & $(.634$ \\
& -.0452 & 1.266 & -.1267 & -.0176 \\
Number of Observations & $(2.568)$ & $(2.577)$ & $(.1782)$ & $(.1811)$ \\
Number of Firms & 16,817 & 16,245 & 45,198 & 43,448 \\
Model & 2,254 & 2,178 & 6,732 & 6,473 \\
Pseudo $R^{2}$ (Logit), Adjusted $R^{2}$ (OLS) & Logit FE & Logit FE & OLS FE & OLS FE \\
\hline
\end{tabular}

Notes: Heteroscedasticity robust standard errors adjusted for firm clusters in parentheses. ${ }^{*},{ }^{* *},{ }^{* *}$ indicates significance at the $10 \%, 5 \%, 1 \%$ level. The observational units are multinational subsidiaries that exhibit a foreign parent which owns at least $90 \%$ of the ownership shares. Additionally, to be included in the estimation, at least one affiliate of the corporate group has to own intangible assets and at least one has to make positive profits. The dependent binary variable is set to 1 if a subsidiary owns intangible assets and is 0 if not. In (1) - (2), a logit model with fixed firm effects (FE) is estimated while in (3) - (4) a linear OLS model with fixed firm effects is applied. The variable Average Tax Difference to All Other Affiliates is defined as the unweighted average statutory tax rate difference between the considered subsidiary and all other affiliates of the corporate group including the parent. All regressions include year dummy variables. Adjusted $R^{2}$ values are calculated from a dummy variables regression equivalent to the fixed-effects model. 


\begin{tabular}{|l|cccccc|}
\hline \multicolumn{6}{|c|}{ Table 5: Robustness Check II: Control for Subsidiary Size } \\
OLS \& IV First Differences, Panel 1995-2005 \\
Dependent Variable: Log Intangible Assets \\
\hline \hline Explanatory Variables: & $(1)$ & $(2)$ & $(3)$ & $(4)$ & $(5)$ & $(6)$ \\
\hline Statutory Tax Rate & $-1.166^{* * *}$ & & $-1.044^{* *}$ & & $-1.845^{* *}$ & \\
& & & $(.4393)$ & & $(.8993)$ & \\
Avg. Tax Difference to & & $-.9235^{* *}$ & & $-.8164^{* *}$ & & $-1.292^{*}$ \\
All Other Affiliates & & $(.4006)$ & & $(.3976)$ & & $(.7648)$ \\
Log GDP per Capita & $.3442^{* *}$ & $.3620^{* *}$ & -.0308 & -.0131 & .2658 & .2741 \\
& $(.1689)$ & $(.1729)$ & $(.1678)$ & $(.1717)$ & $(.3125)$ & $(.3215)$ \\
Log Population & -1.311 & -1.639 & -1.341 & -1.497 & $-3.709^{*}$ & $-4.637^{* *}$ \\
& $(1.527)$ & $(1.540)$ & $(1.459)$ & $(1.473)$ & $(1.946)$ & $(1.966)$ \\
Log Unemployment Rate & $.2004^{* *}$ & $.2047^{* *}$ & $.1955^{* *}$ & $.2011^{* *}$ & .1363 & .1383 \\
& $(.0826)$ & $(.0839)$ & $(.0812)$ & $(.0825)$ & $(.1175)$ & $(.1192)$ \\
Log Total Assets & & & $.5056^{* * *}$ & $.5052^{* * *}$ & -.0441 & -.0388 \\
& & & $(.0299)$ & $(.0305)$ & $(.1841)$ & $(.1876)$ \\
\hline Number of Observations & 37,242 & 35,800 & 37,214 & 35,773 & 19,436 & 18,659 \\
Number of Firms & 6,498 & 6,251 & 6,498 & 6,251 & 4,881 & 4,693 \\
Model & OLS FD & OLS FD & OLS FD & OLS FD & IV FD & IV FD \\
1st-stage F-Test of excl. & & & & & 48.54 & 46.13 \\
instruments (F-statistic) & & & & & & .3461 \\
Hansen J-Test (P-value) & & & & & .1836 \\
\hline
\end{tabular}

Notes: Heteroscedasticity robust standard errors adjusted for firm clusters in parentheses. ${ }^{*},{ }^{* *},{ }^{* * *}$ indicates significance at the $10 \%, 5 \%, 1 \%$ level. The observational units are multinational subsidiaries that exhibit a foreign parent which owns at least $90 \%$ of the ownership shares. Additionally, to be included in the estimation, at least one affiliate of the corporate group has to own intangible assets and at least one has to make positive profits. The dependent variable is the natural logarithm $(\log )$ of the level of intangible assets; we add a small constant to the initial level to avoid losing observations with zero intangibles by taking the logarithm. In (1) - (4), an OLS model in first differences (FD) with no constant is estimated. In (5) - (6), a first-differenced instrumental variables (IV) approach in two stages (2SLS) with no constant is applied, with the 1st difference of Log Total Assets being instrumented with the 2nd - 4th lag of the level of Log Total Assets (cf. Anderson and Hsiao, 1982). The variable Average Tax Difference to All Other Affiliates is defined as the unweighted average statutory tax rate difference between the considered subsidiary and all other affiliates of the corporate group including the parent. All regressions include year dummy variables. Note, time-constant heterogeneity between subsidiaries is controlled for by first-differencing. 


\begin{tabular}{|c|c|c|c|c|c|c|}
\hline \multicolumn{7}{|c|}{$\begin{array}{c}\text { Table 6: Robustness Check III: Dynamic Estimation } \\
\text { Difference GMM, Panel 1995-2005 } \\
\text { Dependent Variable: Log Intangible Assets }\end{array}$} \\
\hline Explanatory Variables: & (1) & (2) & (3) & (4) & $(5)$ & $(6)$ \\
\hline 1st Lag of Log Intang. Ass. & $\begin{array}{l}.8515^{*+* k} \\
(.0241)\end{array}$ & $\begin{array}{l}.8519^{* * * *} \\
(.0246)\end{array}$ & $\begin{array}{l}.8421^{*+* k} \\
(.0217)\end{array}$ & $\begin{array}{l}.8423^{* * *} \\
(.0222)\end{array}$ & $\begin{array}{l}.8351^{* * *} \\
(.0255)\end{array}$ & $\begin{array}{l}.8288^{* * * *} \\
(.0260)\end{array}$ \\
\hline 2nd Lag of Log Intang. Ass. & & & & & $\begin{array}{c}.0018 \\
(.0133)\end{array}$ & $\begin{array}{l}.0035 \\
(.0135)\end{array}$ \\
\hline Statutory Tax Rate & $\begin{array}{r}-1.349^{* *} \\
(.5976)\end{array}$ & & $\begin{array}{r}-1.300^{* *} \\
(.6018)\end{array}$ & & $\begin{array}{r}-1.711^{* *} \\
(.8077)\end{array}$ & \\
\hline $\begin{array}{l}\text { Avg. Tax Difference to } \\
\text { All Other Affiliates }\end{array}$ & & $\begin{array}{l}-1.123^{* *} \\
(.5802)\end{array}$ & & $\begin{array}{r}-1.125^{* *} \\
(.5769)\end{array}$ & & $\begin{array}{l}-1.237^{*} \\
(.7191)\end{array}$ \\
\hline Log GDP per Capita & $\begin{array}{c}.0607 \\
(.1541)\end{array}$ & $\begin{array}{l}.1905 \\
(.1428)\end{array}$ & $\begin{array}{l}-.0394 \\
(.2036)\end{array}$ & $\begin{array}{c}.0872 \\
(.2062)\end{array}$ & $\begin{array}{l}.0795 \\
(.3304)\end{array}$ & $\begin{array}{l}.1195 \\
(.3398)\end{array}$ \\
\hline Log Population & $\begin{array}{l}-2.284^{*} \\
(1.280)\end{array}$ & $\begin{array}{l}-2.182^{*} \\
(1.333)\end{array}$ & $\begin{array}{l}-2.354^{*} \\
(1.238)\end{array}$ & $\begin{array}{l}-2.226^{*} \\
(1.291)\end{array}$ & $\begin{array}{l}-1.655 \\
(1.529)\end{array}$ & $\begin{array}{l}-1.785 \\
(1.538)\end{array}$ \\
\hline Log Unemployment Rate & $\begin{array}{l}.1899^{*} \\
(.1060)\end{array}$ & $\begin{array}{l}.1892^{*} \\
(.1071)\end{array}$ & $\begin{array}{l}.1827^{*} \\
(.1049)\end{array}$ & $\begin{array}{l}.1805^{*} \\
(.1060)\end{array}$ & $\begin{array}{l}.1896 \\
(.1202)\end{array}$ & $\begin{array}{l}.1879 \\
(.1225)\end{array}$ \\
\hline Log Total Assets & & & $\begin{array}{l}.0582 \\
(.0962)\end{array}$ & $\begin{array}{c}.0534 \\
(.0986)\end{array}$ & $\begin{array}{l}-.0241 \\
(.1257)\end{array}$ & $\begin{array}{l}-.0297 \\
(.1301)\end{array}$ \\
\hline Number of Observations & 30,164 & 28,984 & 30,148 & 28,969 & 24,046 & 23,095 \\
\hline Number of Firms & 5,893 & 5,671 & 5,890 & 5,668 & 5,357 & 5,155 \\
\hline Number of Instruments & 22 & 22 & 31 & 31 & 30 & 30 \\
\hline $\begin{array}{l}\text { Arellano-Bond-Test for } \\
\operatorname{AR}(2)(\mathrm{P} \text {-value })\end{array}$ & .356 & .296 & .349 & .290 & .887 & .805 \\
\hline Hansen-Test (P-value) & .432 & .501 & .459 & .441 & .243 & .242 \\
\hline
\end{tabular}

Notes: Standard errors robust against heteroscedasticity and autocorrelation within firms are reported in parentheses. ${ }^{*},{ }^{* *},{ }^{* *}$ indicates significance at the $10 \%, 5 \%, 1 \%$ level. The observational units are multinational subsidiaries that exhibit a foreign parent which owns at least $90 \%$ of the ownership shares. Additionally, to be included in the estimation, at least one affiliate of the corporate group has to own intangibles and at least one has to make positive profits. The dependent variable is the logarithm (log) of the level of intangible assets; we add a small constant to the initial level to avoid losing observations with zero intangibles by taking the logarithm. A one-step linear GMM dynamic panel-data estimation in first differences with no constant is applied. Following Arellano and Bond (1991), we instrument the 1st difference of the 1st Lag of Log Intangible Assets with the 2nd and all deeper lags of the level of Log Intangible Assets. In (3) - (6), we additionally instrument the 1st difference of Log Total Assets with the 2nd and all deeper lags of Log Total Assets levels. The variable Average Tax Difference to All Other Affiliates is defined as the unweighted average statutory tax rate difference between the considered subsidiary and all other affiliates of the corporate group including the parent. All regressions include year dummy variables. Note, time-constant heterogeneity between subsidiaries is controlled for by first-differencing. 


\section{References}

Alesina, A., R. J. Barro, and S. Tenreyro (2002): "Optimal Currency Areas," NBER Working Papers, Working Paper No. 9072, National Bureau of Economic Research.

Anderson, T. W., And C. Hsiao (1982): "Formulation and Estimation of Dynamic Models Using Panel Data," Journal of Econometrics, 18, 47-82.

Arellano, M., and S. Bond (1991): "Some Tests of Specification for Panel Data: Monte Carlo Evidence and an Application to Employment Equations," Review of Economic Studies, 58, 277-97.

Becker, J., And C. Fuest (2007): "Quality versus Quantity - The Composition Effect of Corporate Taxation on Foreign Direct Investment," CESifo Working Paper Series, No. 2126, CESifo Munich.

Brand Finance PlC (2008): "The Increasing Importance of Branding," Brand Finance Report - Brands and tax planning, Issue 3, Twickenham (UK).

Bresnahan, T. F., E. Brynjolfsson, and L. M. Hitt (2002): "Information Technology, Workplace Organization, and the Demand for Skilled Labor: Firm-Level Evidence," Quarterly Journal of Economics, 117(1), 339-376.

Budd, J. W., J. Konings, and M. J. Slaughter (2005): "Wages and International Rent Sharing in Multinational Firms," The Review of Economics and Statistics, 87, $73-84$.

Collins, J. H., D. Kemsley, and M. Lang (1998): "Cross-Jurisdictional Income Shifting and Earnings Valuation," Journal of Accounting Research, 36, 209-230.

Desai, M. A., C. F. Foley, and J. R. Hines (2006): "The Demand for Tax Haven Operations," Journal of Public Economics, 90(3), 513-531.

Devereux, M. P., and R. Griffith (1998): "Taxes and the Location of Production: Evidence from a Panel of US Multinationals," Journal of Public Economics, 68, 335367.

Dischinger, M. (2007): "Profit Shifting by Multinationals: Indirect Evidence from European Micro Data," Munich Economics Discussion Papers, No. 2007-30, University of Munich. 
Dischinger, M., And N. Riedel (2008): "Corporate Taxes, Profit Shifting and the Location of Intangibles Within Multinational Firms," Munich Economics Discussion Papers, No. 2008-11, University of Munich.

Dischinger, M., and N. Riedel (2008b): "Corporate Taxes, Profit Shifting and the Location of Multinational Headquarters," mimeo, University of Munich.

EDmans, A. (2007): "Does the Stock Market Misvalue Intangibles? Employee Satisfaction and Equity Prices," mimeo, MIT Sloan School of Management.

European Commission (2006): "Structures of the Taxation Systems in the European Union," Directorate Generale Taxation and Customs Union, Brussels.

Gattai, V. (2005): "Firm's Intangible Assets and Multinational Activity: JointVenture Versus FDI," Fondazione Eni Enrico Mattei Working Paper Series, No. 122.2005, Bocconi University and ISESAO.

Grubert, H. (2003): "Intangible Income, Intercompany Transactions, Income Shifting, and the Choice of Location," National Tax Journal, 56(1), 221-242.

Grubert, H., And J. H. Mutti (2007): "The Effect of Taxes on Royalties and the Migration of Intangible Assets Abroad," NBER Working Paper Series, Working Paper No. 13248.

Grubert, H., And J. Slemrod (1998): "The Effect of Taxes on Investment and Income Shifting to Puerto Rico," The Review of Economics and Statistics, 80(3), $365-373$.

Hall, R. E. (2001): "The Stock Market and Capital Accumulation," The American Economic Review, 91(5), 1185-1202.

Hejazi, J. (2006): "Assessing the Risks of Intangibles Migration," Tax Management - Transfer Pricing, 15(10), 399-401, The Bureau of National Affairs.

Hilary, G., And C. Lennox (2005): "The Credibility of Self-Regulation: Evidence from the Accounting Professions Peer Review Program," Journal of Accounting and Economics, 40, 211-229.

Hines, J. R., And E. M. Rice (1994): "Fiscal Paradise: Foreign Tax Havens and American Business," Quarterly Journal of Economics, 109(1), 149-182. 
Huizinga, H., And L. Laeven (2008): "International Profit Shifting Within Multinationals: A Multi-Country Perspective," Journal of Public Economics, 92(5-6), 11641182.

KPMG International (2006): "KPMGs Corporate Tax Rate Survey," Corporate Income Tax Rate - A Trend Analysis, 304-250(October 2006).

Markusen, J. R. (1995): "The Boundaries of Multinational Enterprises and the Theory of International Trade," Journal of Economic Perspectives, 9, 169-189.

(2002): Multinational Firms and the Theory of International Trade. The MIT Press, Cambridge.

Morgan Lewis \& Bockius LLP (2007): "Optimising Brand Value Through Strategic Tax Planning," Intellectual Asset Management - Brands in the Boardroom 200\%, April 2007, Washington DC (USA).

Plassmann, F., and T. N. Tideman (2001): "Does the Right to Carry Concealed Handguns Deter Countable Crimes? Only a Count Analysis Can Say," The Journal of Law and Economics, 44, 771-98.

Simpson, G. R. (2005): "Irish Unit Lets Microsoft Cut Taxes in U.S. and Europe," The Wall Street Journal, November 7, 2005, p. A1.

Sullivan, M. A. (2004): "International Tax Planning: A Guide for Journalists," Tax Notes, published by taxanalysts.

Weichenrieder, A. J. (2008): "Profit Shifting in the EU: Evidence from Germany," International Tax and Public Finance, forthcoming.

Zingales, L. (2000): "In Search of New Foundations," Journal of Finance, 55(4), $1623-1653$. 